\title{
From the IJssel Valley to Paris and Rome via Montserrat
}

\section{Ignatius of Loyola and Repositioning the Origins of Modern Piety}

\author{
Robert A. Maryks | ORCID: 0000-0002-8401-4236 \\ Independent Scholar, The Berkshires, MA, USA \\ robert.maryks@gmail.com
}

\begin{abstract}
This essay aims to analyze the hitherto neglected (or deliberately avoided?) link between De spiritualibus ascentionibus (On spiritual ascents) by Zerbolt of Zutphen (1367-1398) and the Spiritual Exercises of Ignatius of Loyola (c.1491-1556). Indeed, there is a more direct relationship between these two texts than between Ignatius's Spiritual Exercises and the Exercitatorio spiritual by Abbot García Jiménez de Cisneros (14551510) and the Imitatio Christi (Imitation of Christ) by Thomas à Kempis (c. 1380-1441), which has received much more attention in the existing literature. A careful synoptic reading of these works reveals not only an intriguing congruence between Zerbolt and Loyola in terms of the scope and definition of their works; the general structure and vocabulary; humanistic soteriology and optimistic anthropology of human will; the role of introspection in reforming inordinate affections and affective devotion; the role of examen of conscience (both daily and general); frequent sacramental confession and Communion; the role of spiritual guide; the use of the five senses and composition of place as meditative techniques and importance of methodical mental prayer; and the centrality of imitation of Christ's humanity, but also direct textual reciprocity. Zerbolt's Spiritual Ascents appears to be a blueprint for Loyola's Exercises.
\end{abstract}

\section{Keywords}

Gerard Zerbolt of Zutphen - Ignatius of Loyola - Devotio Moderna - spiritual exercises - modern spirituality 
The picturesque IJssel Valley in the northeastern Netherlands was formed by the IJssel River, which flows northeastward through it for some 70 miles, connecting the historic Hanseatic market towns of Zutphen, Deventer, Zwolle, and Kampen in the bishopric of Utrecht. In the late 130os-during the time of the papal schism - a religious movement called "Devotio Moderna" (modern, new devotion) marked its presence in those towns. ${ }^{1}$ The principal exponents of this urban movement-which, among other things, stressed conversion, spiritual exercises, affectivity, personalization, interiority, self-discipline, and self-introspection ${ }^{2}$ - were the Brethren of the Common Life, an unprofessed religious community established in the hometown of Geert (Gerard) Groote (b. 1340 in Deventer), ${ }^{3}$ the father of the movement, and a house of Augustinian Canons Regular at Windesheim (near Zwolle), which was founded by Groote's disciples. $^{4}$

The De spiritualibus ascentionibus (On spiritual ascents) by Gerhart (Gerard) Zerbolt (b. 1367 in Zutphen) and the Imitatio Christi (Imitation of Christ) by Thomas à Kempis (b. c. 1380 in Kempis in Rhineland)—Zerbolt's disciple and biographer-are the most representative expressions of the movement's ideas. ${ }^{5}$ They spread to German-speaking lands, northern France, and the Iberian Peninsula, where a group of Benedictines from Valladolid made them part of their reform in the Montserrat monastery in Catalonia. Their abbot, García Jiménez de Cisneros (1455-1510), ${ }^{6}$ compiled for his monks a book of spiritual exercises, Exercitatorio spiritual (1500), ${ }^{7}$ which borrowed heavily from the

1 For a critical review of literature on the Devotio Moderna, see Gerrit H. Gerrits, "Inter timorem et spem": A Study of the Theological Thought of Gerard Zerbolt of Zutphen (1367-1398) (Leiden, 1986), 4-9; John Van Engen, Sisters and Brothers of the Common Life (Philadelphia, 2008), 3-5. For the understanding of the term, see Van Engen, Sisters and Brothers, 7-9.

2 See Kaspar Elm, "The 'Devotio moderna' and the New Piety between the Later Middle Ages and the Early Modern Era," in Religious Life between Jerusalem, the Desert, and the World, trans. James D. Mixson (Leiden, 2006), 317-331.

3 See Van Engen, Sisters and Brothers, 11-13.

4 See Gerrits, "Inter timorem et spem", 1-3; Van Engen, Sisters and Brothers, 154-157. Robert Faesen, “'Individualization' and 'Personalization' in Late-Medieval Thought," in Inwardness, Individualization, and Religious Agency in the Late Medieval Low Countries: Studies in the Devotio Moderna and Its Contexts, ed. Rijcklof Hofman et al. (Turnhout, 2020), 35-50.

5 See Gerrits, "Inter timorem et spem", 10-37, 13-14, 17-18; Van Engen, Sisters and Brothers, 77-81; John H. Van Engen, ed., Devotio Moderna: Basic Writings (New York, 1988), 51-52.

6 See García M. Colombás, o.s.B., Un reformador benedictino en tiempo de los Reyes Católicos: García Jiménez de Cisneros, abad de Montserrat (Montserrat, 1955).

7 For a critical edition of this work, see Cipriano Baraut, o.s.в., ed., García Jiménez de Cis- 
works of the Modern Devout he had brought to his monastery from a trip to Paris, including Zerbolt's De spiritualibus ascentionibus, and had reproduced by the local printing press of Joan Luschner (d. c. 1512). ${ }^{8}$ Among the crucial exercises recommended in Cisneros's compilation (also available as a compendium $)^{9}$ were examination of conscience (examinación de consciencia) and the so-called general confession (confessión general). These became the core of the spiritual experience of Ignatius of Loyola $(c .1491-1556)$, who spent some ten months between 1522 and 1523 in Montserrat and nearby Manresa, following his recent spiritual conversion, and are reflected in what Loyola himself later offered in his own compilation of spiritual exercises in Spanish, the Exercicios spirituales. ${ }^{10}$

Given the hagiographical and rhetorical character of the accounts of Ignatius's life by his contemporary biographers-including what is uncritically considered Loyola's autobiography (which, at any rate, does not mention the composition of the Exercises in Manresa or Montserrat) ${ }^{11}$ — and the scarcity of reliable historical sources, the history of the composition of this text is hard to reconstruct with precision. The attempts to do so for the period before 1535

neros: Obras completas (Montserrat, 1965). See the digital copy of the Latin edition at https://www.google.com/books/edition/Exercitatorium_vitae_spiritualis/UZ31LttIUk4C ?hl=en and of the Spanish one at https://www.google.com/books/edition/Exercitatorio _de_la_vida_espiritual/ulbvP_9BgesC?hl=en (accessed December 6, 2020). Both were printed by Luschner in Montserrat in 1500. Albert Hyma claimed that Cisneros printed 8oo copies of De spiritualibus ascentionibus (see Albert Hyma, The Christian Renaissance: A History of the Devotio Moderna [The Hague, 1924], 267).

8 Two Latin editions were printed in Montserrat in 1499, also by Luschner, both of which are in the octavo format (see their digital copies at http://bdh-rd.bne.es/viewer.vm?id $=0000176323 \&$ page $=1$ and https: $/ /$ mdc.csuc.cat $/$ digital $/$ collection $/$ incunableBC/id $/ 16496$ ? [accessed December 6, 2020]). See I. Rodriguez-Grahit, "Ignace de Loyola et le Collège Montaigu: L' influence de Standonck sur Ignace," Bibliothèque d'humanisme et Renaissance 2o, no. 2 (1958), 388-401, there 399n7. There were at least four Parisian printings of Zerbolt's works in the 1490 os (see Gerrits, "Inter timorem et spem", 35-36).

9 See Javier Melloni, The Exercises of St Ignatius Loyola in the Western Tradition (Leominster, 200o), 2-3, 8-11; Melloni, ed., Compendio breve de ejercicios espirituales (Madrid, 2006).

10 The original text has not been preserved. What we have is what is called the "Autograph"a copy by an amanuensis with original corrections of Ignatius. It was first published in 1615 . For the critical, annotated edition of the text, see José Calveras and Cándido de Dalmases, eds., Sancti Ignatii de Loyola Exercitia spiritualia [Monumenta Histórica Societatis Iesu] (Rome, 1969).

11 See the description of Loyola's stay in Montserrat and Manresa in Obras de san Ignacio de Loyola, ed. Ignacio Iparraguirre, S.J., and Cándido de Dalmases, s.J. (Madrid, 1991), 111121 ([19]-[34]), which does not mention his composition of the Exercises there, and the editors note that they find it curious (121n23). 
are — as Rogelio García Mateo, s.J., puts it — mere conjectures, ${ }^{12}$ and they disregard the historical methods of literary criticism. Available sources indicate that the expression "spiritual exercises" appears for the first time in any Ignatian text that we know of only in November 1536, a year after he had left Paris-in Loyola's letter to his Erasmist confessor Manuel de Miona (c. 1477-1567), who followed him from Spain to Paris. ${ }^{13}$ It is, therefore, more reasonable to conclude that Loyola's more systematic studies at the University of Paris over a period of seven years (1528-1535), which concluded with an officially recognized academic degree, gave him more stability, time, and tools to absorb the philosophical and theological vocabulary and "digest" his earlier spiritual experiences, so that he could write down his devotional program for others. Indeed, the oldest manuscript copies of the Exercises that we know of were written post-1535. $\cdot^{14}$

In this context, it does not come as a surprise that the Devotio Moderna marked its influence in Paris (just as it did in Montserrat) before Loyola's arrival there. Jan Standonck (1453-1504), for instance, to whom Abbot Cisneros had paid a visit in the late 1490 o,$^{15}$ founded the Collège de Montaigu there - a structure for poorer students similar to the Brethren of the Common Life's hostels (bursae). It required the reading of the Devout Jan Mombaer's (c. 146o-1501) Rosetum exercitiorum spiritualium et sacrarum meditationum (Rosary of spiritual exercises and sacred meditations) — a work that together with Zerbolt was copied by Cisneros - and of à Kempis's Imitatio. ${ }^{16}$ Like Erasmus of Rotterdam (1466-1536) and John Calvin (1509-1564) before him, Ignatius stayed and studied at the Collège de Montaigu, where he had access to a library that contained not a few volumes produced by the Devout, including Zerbolt's. ${ }^{17}$

In those Parisian years, Loyola employed his Spiritual Exercises to recruit some much younger students to join his group of "friends in the Lord" - a sort

12 See Jean-François Gilmont, “Découvertes récentes sur l'histoire de la rédaction des Exercices," Revue d'histoire ecclésiastique 66 (1971), 618-625. Cf. Rogelio García Mateo, "The 'Accommodated Texts' and the Interpretation of the Spiritual Exercises," The Way 44, no. 1 (January 2005 [1994]), 101-116, there 105-106.

13 See Saint Ignatius of Loyola, Personal Writings, ed. and trans. Joseph A. Munitiz and Philip Endean (London, 1996), 138-139, there 138.

14 Cf. García Mateo, "Accommodated Texts," 106-109.

15 See Jacob Needleman, Money and the Meaning of Life (New York, 1994), 3 o8.

16 See Van Engen, Sisters and Brothers, 317-318.

17 Hyma, Christian Renaissance, 271-272; Kenneth A. Strand, John Calvin and the Brethren of the Common Life (Berrien Springs, MI, 1975), 283-284; I. Rodriguez-Grahit, "La Devotio moderna en Espagne et l'influence française," Bibliothèque d'humanisme et Renaissance 19, no. 3 (1957), 489-495, there 494 n. 
of a community of brethren of the common life. Vowed to live in chastity and poverty but without choosing anyone as their superior, they shared Ignatius's plan to travel to the Holy Land to proselytize among Muslims once they had completed their studies. Unable to embark for that trip in Venice, they eventually descended to Rome, where - after a few months of discernment - they decided to co-found an as-soci-ation of brethren known as the Society of Jesus (Jesuits). ${ }^{18}$

The impact of late medieval and early modern devotional literature on Loyola's Exercises has been acknowledged by scholars, including the influence of the Carthusian Ludolph of Saxony's (c. 1295-c. 1378) Vita Christi (Life of Christ, 1374) on the narrative of the meditations in Loyola's text; ${ }^{19}$ the influence of Erasmus's Enchiridion militis christiani (Handbook of a Christian knight, 1503-1504) on the composition of the Exercises' Principle and Foundation and of his Paraphrasis in Evangelium Matthaei (Paraphrasing Matthew's Gospel, 1522) on the Rules for the Discernment of Spirit; ${ }^{20}$ and-more recently—the influence of the works by Antonio da Atri (d. 1522) and Battista da Crema (fl. 145os) on Loyola's Meditation on the Two Standards. ${ }^{21}$ And, of course, the scholarship on à Kempis's Imitation of Christ - the only devotional work mentioned explicitly in his Spiritual Exercises - has been abundant. ${ }^{22}$

Zerbolt, in contrast, has received disproportionally less attention, and it seems that some scholars have deliberately dismissed or downplayed his role as a source for Loyola. Between the late nineteenth and throughout the twenti-

18 It is interesting to note that the term "society" (Lat. societas for "companionship") is the same term used in middle Dutch to describe the communities of the Devotio Modernaghesel-scop (ghesel for companion), which is etymologically related to the German Gesellschaft. Indeed, the German term for the Society of Jesus is Gesellschaft Jesu. Cf. Van Engen, Sisters and Brothers, 82, 310.

19 Paul Shore, "The Vita Christi of Ludolph of Saxony and Its Influence on the Spiritual Exercises of Ignatius of Loyola," Studies in the Spirituality of Jesuits 30, no. 1 (1998).

$20 \quad$ See Terence O'Reilly, "Erasmus, Ignatius Loyola, and Orthodoxy," Journal of Theological Studies 30, no. 1 (1979), 115-127, there 119.

21 Adriano Prosperi, "The Two Standards: The Origins and Development of a Celebrated Ignatian Meditation," Journal of Jesuit Studies 2, no. 3 (2015), 361-386. For other inquiries on the sources of the Exercises, see Juan Plazaola, s.J., ed., Las fuentes de los Ejercicios espirituales de San Ignacio (Bilbao, 1998) and José Calveras, S.J., and Cándido de Dalmases, S.J., eds., Exercitia spiritualia (Rome, 1969), 34-6o.

22 Attributed at the time of Loyola to Jean Gerson (1363-1429), a chancellor of the University of Paris, and hence called in the early Jesuit circles "Gersoncito." See, for example, chapter 10 of Maximilian von Habsburg, Catholic and Protestant Translations of the Imitatio Christi, 1425-1650: From Late Medieval Classic to Early Modern Bestseller (New York, 2016), 180-217; Terence O'Reilly, "Early Printed Books in Spain and the Exercises of Ignatius Loyola," Bulletin of Spanish Studies 89, no. 4 (2012), 635-664. 
eth century, the authoritative Jesuit scholars of the Exercises acknowledged the influence of the Devout of Zutphen on Ignatius to a greater or lesser degree. The pioneer in the studies on the sources of the Exercises, Henri Watrigant (1845-1926), claimed that Zerbolt had an indirect influence on the Spiritual Exercises by showing how Loyola's text was indebted to Cisneros, for he had copied abundantly from Zerbolt. Noticing an obvious "great analogy" between the structures of the two texts, Watrigant also suggested that Ignatius read De spiritualibus ascentionibus, likely during his sojourn in Paris, for on several points he is closer to Zerbolt than to Cisneros. ${ }^{23}$ The latter point was reaffirmed by Watrigant's colleague Paul Debuchy (1862-1923) in his article on the Spiritual Exercises in The Catholic Encyclopedia, in which he also highlighted how their pragmatism made Zerbolt and Loyola akin. ${ }^{24}$

In his study on the practice of the Spiritual Exercises, Ignacio Iparraguirre (1911-1973) mentions Zerbolt's De spiritualibus ascentionibus in the context of the methodical prayer characteristic of the Devotio Moderna but dismisses Watrigant's points of analogy between the two texts, even if he cites the latter's work in reference to other aspects. ${ }^{25}$ The same categorical refusal to acknowledge any literary dependence of the Exercises characterizes the critical editions of the text by Iparraguirre and his Spanish confrères, José Calveras (1890-1964) and Cándido de Dalmases (1906-1986). ${ }^{26}$

In contrast, another Spanish Jesuit historian, Ricardo García Villoslada (1900-1991), noted Watrigant's bold claim of how the Devotio Moderna became a bridge for the Exercises and the rejection of this approach by another Spanish Jesuit Arturo Codina. ${ }^{27}$ García Villoslada, for his part, did not want to declare with whom he sided, but he seemed to support the "perfectly equilibrated" via media between Watrigant and Codina, represented in his view by the French Jesuits Paul Dudon (1859-1941) and Joseph de Guibert (1877-1942), and the Spanish Jesuit Pedro de Leturia $(1891-1955){ }^{28}$

23 La genèse des exercices de saint Ignace (Amiens, 1897), 209-211.

24 "Spiritual Exercises of Saint Ignatius," in The Catholic Encyclopedia (New York, 1912), http:// www.newadvent.org/cathen/14224b.htm (accessed November 23, 2020).

25 Práctica de los Ejercicios de San Ignacio de Loyola en vida de su autor (1522-1556), 2 vols. (Bilbao, 1946), 1:3o.

26 Ignacio Iparraguirre, ed., Obras completas de san Ignacio (Madrid, 1963), 177; Iparraguirre and Dalmases, Obras de san Ignacio de Loyola, 197-198 (no alteration of the text with regard to the sources in both editions); and José Calveras and Cándido de Dalmases, eds., Sancti Ignatii de Loyola Exercitia spiritualia et eorum Directoria (Rome, 1969), 51-52.

27 "Rasgos característicos de la Devotio Moderna," Manresa 28 (1956), 315-350, there 316-317. Cf. Arturo Codina, ed., Exercitia S. Ignatii et eorum Directoria (Madrid, 1919); Codina, Los orígenes de los Ejercicios espirituales de San Ignacio (Barcelona, 1926).

28 Paul Dudon, Saint Ignace de Loyola (Paris, 1934), 261-29o; Joseph de Guibert, La spiritualité 
Among contemporary Jesuit scholars of the Exercises, Javier Melloni has demonstrated how the Exercises are indebted to Cisneros, especially his abridged version of the Ejercitatorio known as Compendio breve, and he is aware that these works are a compilation of an earlier spiritual tradition that included Zerbolt and Mombaer, but he does not expressly acknowledge Zerbolt's direct influence on Loyola (although his table, "Genealogy Tree of the Exercises," might suggest that). Robert Faesan, in contrast, considers Zerbolt's De spiritualibus ascentionibus a "surprising precursor to the Spiritual Exercises." 29 The scholars of the Devotio Moderna, whose study did not usually specialize in the Spiritual Exercises, acknowledged De spiritualibus ascentionibus as potential source for the Exercises with more or less conviction but usually in rather generic terms. ${ }^{30}$

This essay offers a synoptic critical reading of both texts by Zerbolt and Loyola in their entirety to show that there is not just some sort of indirect link, similarity, or analogy between the Spiritual Ascents and the Spiritual Exercises but that the former is a blueprint for the latter. ${ }^{31}$ Indeed, there is a more direct relationship between these two texts than between the ones by Ignatius and Cisneros and à Kempis. ${ }^{32}$ Of course, both Zerbolt and Loyola are indebted to a much longer and larger spiritual tradition, as I shall point out below in the footnotes, but a more careful reading of these works - whose originals were written in two different languages - reveals a unique congruence between Zerbolt and Loyola. This congruence is multifaceted and can be detected not only in terms of the scope and definition of their works; the general structure and vocabulary; humanistic soteriology and optimistic anthropology of human will; the

de la Compagnie de Jésus (Rome, 1953), 141-156; Pedro de Leturia, "La Devotio moderna en el Montserrat de San Ignacio," Razón y fe 111 (1936), 371-385.

29 Melloni, Exercises of St Ignatius Loyola in the Western Tradition, 6-8, 12-13; Robert Faesan, "Tentamen vitae contemplativae in actione: The Doctrine of the Devotio Moderna," in In Lutero 500 Anni dopo: Una rilettura della Riforma Luterana nel suo contesto storico ed ecclesiale, ed. Gert Melville et al. (Vatican City, 2019), 69-89, there 78.

30 See, for example, Hyma, Christian Renaissance, 270-271; R[egnerus] R[ichardus] Post, The Modern Devotion: Confrontation with Reformation and Humanism (Leiden, 1968), 326; Mark Chinca, Meditating Death in Medieval and Early Modern Devotional Writing: From Bonaventure to Luther (Oxford, 2020), 176 ff.; Otger Steggink, "De moderne Devotie in het Montserrat van Ignatius van Loyola," Ons Geestelijk Erf 59 (1985), 383-392.

31 Hyma, Christian Renaissance, 270-271.

32 Cf. Moshe Sluhovsky, "St. Ignatius of Loyola's Spiritual Exercises and Their Contribution to Modern Introspective Subjectivity," Catholic Historical Review 99, no. 4 (2013), 649-674, there 649-65o. See also Iparraguirre and Dalmases, Obras de san Ignacio, 197. Cf. Gerrits, "Inter timorem et spem", 36; Melloni, Exercises of St Ignatius, 1; and Hyma, Christian Renaissance, $270-271$. 
role of introspection in reforming inordinate affections and affective devotion; the role of examen of conscience (both daily and general); frequent sacramental confession and Communion; the role of spiritual guide; the use of the five senses and composition of place as meditative techniques and importance of methodical mental prayer; and the centrality of imitation of Christ's humanity, but also direct textual reciprocity.

Many of these common features characterize what scholars define as modern religiosity. They show that the method of Ignatius's Exercises is not as novel as it is often apologetically and simplistically portrayed by some scholars (as discussed above) but deeply rooted in the late medieval tradition of the Devotio Moderna, which emerged in the IJssel Valley some one hundred years before Ignatius was born. Loyola, therefore, should be seen more as a late representative of the Devotio Moderna who bridged this novel spirituality into the sixteenth century than as the founder of modern religiosity, a portrayal uncritically promoted by the influential Jesuits Karl Rahner (1904-1984) and his brother Hugo (1900-1968). ${ }^{33}$

Loyola's disciples quickly grew in numbers and expanded disproportionally more than the Brethren of the Common Life-they traveled overseas on colonial ships to Asia, Africa, and the Americas, while the communities of Brothers (and Sisters) of the Common Life were being shut down by both Catholic and Protestant authorities, and the popularity that Zerbolt's works enjoyed in the fifteenth century sharply declined in the second half of the sixteenth. ${ }^{34}$ The Jesuits took the baton from the Devout and made the ideals of the Devotio Moderna more popular, as giving Spiritual Exercises and promoting several devotional practices contained therein, such as frequent examination of conscience, general confession, frequent sacramental confession and Communion, and spiritual direction, became a fundamental part of their ministerial advocacy.

Experts in propaganda, the Jesuits made sure that the Exercises received the highest blessing. Indeed, Pope Paul III (r. 1534-1549) officially approved Loyola's Latin text in 1548, stating in his breve that it "will be extremely useful and salutary for the spiritual profit of the faithful."35 Its many editions and translations began being printed around the world. ${ }^{36}$ Some 400 years later, Pope Pius XI (r.

H. Outram Evennett, The Spirit of the Counter-Reformation, ed. John Bossy (Cambridge, 1968), 126-127.

34 See Van Engen, Sisters and Brothers, 4-5.

35 See the text of the brief Pastoralis officii cura, https://www.catholicculture.org/culture/ library/view.cfm?recnum=8629 (accessed December 7, 2020).

36 Ignacio Iparraguirre, s.J., Historia de los Ejercicios de San Ignacio, vol. 2, Desde la muerte de 
1922-1939) declared Ignatius "the chief and peculiar Master of Spiritual Exercises" and the saint patron of all spiritual exercises, ${ }^{37}$ as if their origins belonged to him. The following part of the essay shows the roots of Loyola's Spiritual Exercises in Zerbolt's Spiritual Ascensions.

\section{Definition and Scope of the Two Works}

Even if Zerbolt's Spiritual Ascents - written in the polished Latin of a learned, even if very young, librarian-was conceived as a devotional manual for "all who want to make progress in spiritual life,"38 and Loyola's Spiritual Exercisescomposed in the crude Spanish of a former knight—originated as a guide for laymen, ${ }^{39}$ both texts aim at the same goal of offering practical advice on what steps (of the ladder extended to God, in Zerbolt's words) need to be taken to reform (reformare; reformar), amend (emendare; enmendar), correct (correggere; corregir), or arrange (ordenar; ordinare $)^{40}$ one's life through an ascetical

San Ignacio hasta la promulgación del Directorio oficial (1556-1599) (Bilbao, 1955), 352-359.

See the text of his encyclical Mens nostra, http://www.vatican.va/content/pius-xi/en/ encyclicals/documents/hf_p-xi_enc_19291220_mens-nostra.html (accessed December 7, 2020).

38 The subtitle of the mid-145os Deventer edition reads: "Omnibus in spirituali vita proficere volentibus." More than 100 manuscript copies and 29 print editions of De ascentionibus have survived. See Van Engen, Devotio Moderna, 51. Gerrits, "Inter timorem et spem", 2733; Gérard Zerbolt de Zutphen, La montée du coeur = De spiritualibus ascensionibus, ed. Francis-Joseph Legrand (Turnhout, 2007), 42-56.

39 After the foundation of the Society of Jesus, however, it did become the main reference for Jesuit spirituality.

40 Both Zerbolt and Loyola use these terms interchangeably or by pairing, with Zerbolt preferring "reformare" (the very title of Zerbolt's other work is De reformatione interiori seu virium animae) and Loyola "e[n]mendar," but both use the combination of "amend" and "correct." Loyola's ordenar in this context (put order in one's life) appears only once but in the very title of his work. Zerbolt also uses ordinare once in reference to "external man." It should be pointed out, however, that the lack of order is reflected in their use of the adjectives "disordinate" or "inordinate" in reference to affections. It is interesting to note that both the Latin and Spanish original terms have the same etymological roots. See Sebastián de Covarrubias Orozco, ed., Tesoro de la lengua castellana, o Española (Madrid, 1673-1674), s.v. "emendar," "ordenar," "reformar"; Charlton T. Lewis and Charles Short, eds., A Latin Dictionary (Oxford, 1879), s.v. "emendo," "ordino," "reformo."

I follow the English translation of the Spiritual Exercises from the autograph by Elder Mullan (http://www.documentacatholicaomnia.eu/o3d/1491-1556,_Ignatius_Loyola,_Spir itual_Exercises,_EN.pdf [accessed December 7, 2020]) and the English translation of the Spiritual Ascents by J.P. Arthur (London, 1908) with appropriate modifications of mine. I use the Spanish original of the former published in Ignacio Iparraguirre, Cándido de 
program of spiritual exercises that consists in getting rid of vices and progressing in the virtues. ${ }^{41}$

Although Zerbolt — unlike Loyola - does not provide a specific definition of the concept, his spiritual ascents are indeed spiritual exercises he sometimes calls "holy" (sancti) or "devout" (devoti), terms that are scattered throughout his work. ${ }^{42}$ Indeed, Zerbolt represents here the original tradition of the Devotioto the founder of the movement, Groote, is ascribed a text that included a discussion of the exercises of the devout, De (cohabitatione et) exercitiis devotorum. ${ }^{43}$ The main focus of the exercises for both Zerbolt and Loyola are inordinate affections.

Central Focus on Inordinate Affections

In the chapter dedicated to the meditation on hell (21), Zerbolt indicates the crucial interaction between spiritual exercises and inordinate affections in recuperating the original (prelapsarian) "quiet and peaceful an agreement of affections [affectuum quieta et pacifica concordia]" (2): "By these and like meditations [meditationibus] thou shalt conceive [concipies] the fear [timorem] of the Lord, and prepare [conficies] a salutary compunction, so that

Dalmases, and Manuel Ruiz Jurado, Ignacio de Loyola: Obras completas (Madrid, 1997) and the Latin original of the latter published in Maxima bibliotheca veterum patrum [...], vol. 26 (Lyon, 1677). I have also consulted the critical edition of Zerbolt's treatise edited by Francis-Joseph Legrand.

41 The 1539 Cologne edition of both of Zerbolt's treatises has a subtitle: "Ad vitam corrigendam recteque instituendam" (To correct and order life properly). Cf. Iparraguirre, Historia de la práctica de los ejercicios espirituales, 1:29-30, where the Jesuit historian defines their goal as "methodic prayer, retreat, and [spiritual] direction [oración metódica, retiro, dirección]" and suggests that Ignatius fuses these three elements for the first time in an original and harmonious way, but—as we can see here — that "fusión original y armoniosa" is already present in Zerbolt.

42 In chapter 9, for example, Zerbolt explains that "a man ought first of all to determine in his heart what his spiritual exercises should be"; in chapter 51 , he argues how "it is expedient or necessary for a man who is going forward in spiritual exercises to have for a guide a man that is spiritual"; in chapter 43, he warns that it "is not within the power of human frailty always to be instant in climbing these upward steps of the heart, in forming spiritual affections and doing spiritual exercises"; and in chapter 45, he advises that "a morning hour is most convenient, because at such a time a man is more grave and better disposed toward spiritual exercises, not yet being involved in the turmoil of worldly things."

43 This tradition is also reflected in the title of Mombaer's work, Rosetum exertitiorum spiritualium. See Van Engen, Devotio Moderna, 31: "Although the notion of exercise was not original with them, the New Devout gave it an emphasis rarely or never found earlier." 
by such means thou mayest tear away [avellas] thine affections [affectiones] from the lowest things [rebus infimis]; but it doth behove thee to continue [immorari] for a great while [longo tempore] in these exercises [his exercitiis] and to purge [expurgare] the said affections by meditations [meditationibus]." ${ }^{4}$ Loyola echoes this correlation in both the subtitle of his booklet-the aim of the spiritual exercises is "to conquer oneself and arrange [ordenar] one's life without determining oneself through any affection [affección] that is disordered [desordenada]" - and in his own definition of spiritual exercises as "every way of preparing and disposing the soul to rid itself [quitar] of all the disordered affections [las afecciones desordenadas]."45

Both Zerbolt and Loyola indicate that, to put order in one's life, inordinate affections must be "subjected to the rule of reason"-which is a gift of the Creator-through the exercise of will, which remains a positive element in man after the Fall. ${ }^{46}$ Zerbolt explains that "after long strife and many exercises and with the cooperation of the grace of God, a man hath already made vice itself subject to the rule of reason [vitia imperio rationis subegit]" (49). ${ }^{47}$ Loyola, in his explanation of the purpose of exterior penances, writes that "to conquer oneself $[\ldots]$ is to make sensuality obey reason and all inferior parts be more subject to the superior [para que la sensualidad obedezca a la razón y todas partes inferiores estén más subiectas a las superiores]" (87).

Both Zerbolt and Loyola stress the importance of introspection of one's inordinate affections in order to uproot them. Zerbolt writes: "Thou dost learn [discis] by bestirring thee [advertere] after this fashion to recognize [cognoscere] thine inward [interna] vices, to see [videre] thine inordinate affections and concupiscence and to ponder [considerare] the disordered state of the powers of thy soul [virium animae tuae deordinationes]; but yet thou shalt never be able to see [videre] fully and perfectly how strong and deeply rooted such affections are" (8). Loyola follows Zerbolt by inviting the retreatant to pray "that I may feel an interior knowledge [interno conoscimiento] of my sins, and hatred [aborrescimiento] of them; [...] that I may feel the disorder of my actions

44 On two occasions, Zerbolt also uses the term "motus inordinati" (2 and 7).

45 Both Zerbolt and Loyola are part of an established medieval tradition of spiritual manuals, including John Cassian's commentary on the Institutes of the Coenobia, John Climacus's Scala Paradisi, William of St. Thierry's Epistola ad fratres de Monte Dei, David of Augsburg's De exterioris et interioris hominis compositione, Bonaventure's De triplici via, and García Jiménez de Cisneros's Ejercitatorio spiritual, among others.

46 See Gerrits, "Inter timorem et spem", 69, 84-85, 167.

47 See also Zerbolt, 52: "The noxious inclinations are curbed with the bridle of reason [noxiae monitiones freno rationis moderantur]." 
[dessorden de mis operaciones], so that, hating them, I may correct myself and put myself in order [me enmiende y me ordene]" (63).

Both Zerbolt and Loyola recognize (within the traditional, orthodox theological framework) the double origin of inordinate affections - in the original sin of Adam and in individual sins. Zerbolt explains that "the inordinate affections [...] were born [innatas] in thee because of Adam, or have been implanted [inolitas] in thee by thine own act" (11), "for we all were in [Adam] by virtue of the force of parenthood and the law of descent, wherefore we all are fallen" (3). ${ }^{48}$ Loyola, in the meditation on the sin of "our first parents," writes "how much corruption came on the human race [and] so many people going the way to hell" because of their sin and the loss of original justice (la justicia original), and invites the exercitant, afterward, to meditate on the "particular sin of any one who for one mortal sin is gone to hell—and many others without number, for fewer sins than I have committed" (51).

Both authors indicate why it is difficult to extirpate inordinate affectionsfor Zerbolt, they are "ingrained by habit" (15) and "habituated to vice" (49), ${ }^{49}$ and Loyola employs the concept of "habit of sinning" (hábito de pecar) (242). Hence, both Zerbolt and Loyola suggest the same strategy to root them out. Zerbolt writes that "these thou must purge away and get thee gone from them, one by one" (15) and that "a man ought not to fight against all [vices] at one time, but against some one chief vice" (53), ${ }^{50}$ and Loyola advises that "one ought to propose to guard himself with diligence against that particular sin or defect that he wants to correct and amend" (24).

For both Zerbolt and Loyola, inordinate affections are not only related to mortal, especially the seven deadly sins, ${ }^{51}$ or venial sins, but also those vices "wearing the appearance of goodness [bonitatis apparitione], like an inordinate affection for preaching, which doth seduce by wearing the cloak of a zeal

48 See also Zerbolt, 4: "This impurity thou hast gotten through the fall of the first man; but by thine own continuance therein, by thine own affection and cleaving to it, thou hast added much more thereto, so that he that was foul at the first is now become yet fouler," and Zerbolt, 52: "All inordinate affections that do arise chiefly because of that disorder of the powers of thy soul which hath been brought about through thy first descent from original justice." See Gerrits, "Inter timorem et spem", 73.

49 Loyola acknowledges the concept of habitual sinning in the section dedicated to the three methods of prayer: "It is to be noted that when one comes to think on a Commandment on which he finds he has no habit of sinning, it is not necessary for him to delay so much time."

50 A term used for this practice among the Brothers and Sisters of the Common Life was "spiritual carpentry." See Van Engen, Brothers and Sisters, 301.

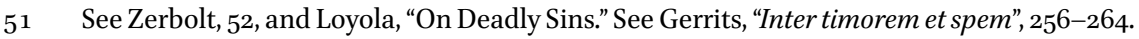


for souls, and urgeth one on through the lust of praise and the desire of reputation" (Zerbolt, 54), for "the enemy of human nature tempts under the appearance of good [debaxo de especie de bien]" (Loyola, 10).

Moving within the same traditional soteriological framework of the redemption of Adam's original sin through Christ's expiation, ${ }^{52}$ Zerbolt's and Loyola's shared goal is to offer help to sinful man, living in this "valley of tears to which mankind hath fallen" (Zerbolt, 1), to return to their original prelapsian state of contemplating God, the state of "natural and primitive worthiness in which God did set man in the beginning" (Zerbolt, 2), for "man is created to praise, reverence, and serve God our Lord, and by this means to save his soul" (Loyola, 23). 53

In order to achieve such a goal, both Zerbolt and Loyola indicate the same three-part pedagogical vademecum, or a triple path, to use Bonaventure's (12171274) expression, whether divided into three ascents/descents or four "weeks": (1) to instill fear of God "the terrible Judge" (Zerbolt) and "the Supreme Eternal Judge" (Loyola) and purge the heart from "hurtful affections and attachments" (Zerbolt, 22);54 (2) to instill hope "to follow and imitate Our Lord, so lately incarnate" (Loyola, 109) and "stretch forth in his heart to an affection towards, and a love for, the humanity of Christ in such a manner that every affection and appetite that is in him may have reference to the sweetness of that humanity" (Zerbolt, 27);55 and finally (3) "while putting behind [...] the tumult of [...]

$5^{2}$ Zerbolt, 38: "For the remission of such guilt so great a price was required, an expiation so mighty, a medicine so hard to attain." Loyola: "Imagining Christ our Lord present and placed on the Cross, let me make a Colloquy, how from Creator He is come to making Himself man, and from life eternal is come to temporal death, and so to die for my sins." See Gerrits, "Inter timorem et spem", 137-138.

53 Cf. Zerbolt, 32: "Dost also see Him with thy mind's eye as God Almighty whose meed is fear, reverence and adoration, thy Creator and thy Judge."

54 "By means of fear of judgement to come and dread of punishment, making all our inward thoughts to quake as it were, and withdrawing them from corrupt affections [vitiosa affectio] and from cleaving [inhaesio] to lower things." See also 15: "Noxiis inferiorum affectionibus et inhaesionibus" and "inordinata affectione inhaeres rebus infimis." In contrast, man should be able to cleave (inhaerere) to $\operatorname{God}(27,38)$.

55 See also chapter 27 , where he explains that the devout exercises are "founded upon the life and death of Christ," and the conclusion of chapter 36 , where he invites the exercitant as follows: "Conform Thy conduct to the pattern of the imitation of Christ [effigiem 
temporal acts [to] search out the sentence of the Heavenly Will, looking down from the peak of [...] contemplation" (Zerbolt, 70) and be "able in all to love and serve His Divine Majesty" (Loyola, 233).

To achieve purity of heart, both Zerbolt and Loyola propose the same preliminary ascetical path-introspection and self-examination (examen of conscience) of inordinate affections that through meditations on sin and God's justice and mercy and other exercises "by which a man may strike terror into himself" (Zerbolt, 20) and produce "contrition, sorrow and tears for [...] sins" (Loyola, 4); subsequent general, oral confession of sins to a confessor who "doth know how to remit or retain sins with discretion and prudence" and "is wishful to use the milder remedies" (Zerbolt, 13); sacramental reconciliation; and frequent reception of the Blessed Sacrament, which is "a food most needful to sustain thee in the way by which thou goest up, and for this cause it hath obtained this name and is called viaticum" (Zerbolt, 31), "an aid not only not to fall into sin, but also to preserve the increase of grace" (Loyola, 44).

From this understanding of Communion as viaticum (from Latin "provision for a journey") follows the authors' encouragement to receive it frequently. Zerbolt argues that "for this cause it is needful for thee often to prepare thyself to holy participation in this Sacrament, because just as this Food, well and worthily received, doth confer upon the soul a mighty and abundant grace" (31). In his rules on the sentiments with the church militant, a later addition to the text of the Exercises, ${ }^{56}$ Loyola invites the reader "to praise confession to a priest, and the reception of the most Holy Sacrament of the Altar once in the year, and much more each month, and much better from week to week, with the conditions required and due., 57

The extirpation of inordinate affections and attachments and restoration of what they both call "powers of the soul" (potencias del ánima; vires animae) starts for Zerbolt and Loyola with the examen of conscience, and they dedicate

imitationis Christi], that is a pattern of kindliness, of severity, humility, and foresight [perspicuitatis]." See Gerrits, "Inter timorem et spem", 157-158.

$5^{6}$ See O'Reilly, "Erasmus, Ignatius Loyola, and Orthodoxy," 121-122.

57 Invitation to frequent confession and Communion characterized the ministry of the first Jesuits. One of the very first books published by a Jesuit was in fact on frequent Communion-Cristóbal de Olave's De frequenti usu sanctissimi Eucharistiae Sacramenti libellus (Rome, 1557). See Robert A. Maryks, Saint Cicero and the Jesuits: The Influence of the Liberal Arts on the Adoption of Moral Probabilism (Aldershot, 2008), 19-23. It seems that frequent reception of Eucharist was indeed characteristic of the spirituality of the Devotio Moderna as a whole. Cf. John W. O'Malley, The First Jesuits (Cambridge, MA, 1993), 152, and Gerrits, "Inter timorem et spem", 225. See also Iparraguirre and Dalmases, Obras de san Ignacio, $115 \mathrm{n} 5$. 
a significant part of their texts to this exercise, which should be done "often if not continually" (Zerbolt, 4).

\section{$5 \quad$ Examen of Conscience}

Zerbolt advises that "thou oughtest diligently to arouse thyself and make strict examination, so that at length thou mayest open thine eyes, and be able to see whither thou hast fallen and where thou liest." He suggests three kinds of examination that consist mainly in the remembrance (ad memoriam reducere) of $\sin .{ }^{58}$ The first one should focus on "how great hath been thy grievous fall" from the perspective of how God "for disobedience [...] cast Adam forth from Paradise, and despoiled all mankind of original justice," so that man is "smitten with fear and overwhelmed with horror." Consequently, "recollection should come and bring forward into the midst all thy grievous sins of the past, and above all the chiefest of them [...] by which thou hast offended God Almighty, the terrible Judge, the Father kind and bountiful, Who hath done so great things for thee and hath sustained thee; and how in a manner that thou hast crucified Him afresh" (6).

Zerbolt explains the second kind of examination, which is general, as follows: "In order that thou mayest perceive more clearly the nature of all vices and passions in general, thou oughtest sometimes and at fitting opportunity to bestir thyself in another manner also, and to make earnest examination concerning thy whole state, both inward and outward" (7). The third type of examination, the daily one done by the end of the day, requires diligently looking backward and strictly considering "how often thou hast been drawn to things unlawful through thine evil habits, and above all how often that vicious and clinging impurity hath hampered thee during the day" (8).

Loyola's concept of examen of conscience-reflecting Zerbolt's traditional tripartite division into words, thoughts, and deeds (31) — consists in the same technique of remembrance of sin, what he calls "traer [a, en] la memoria" (bringing [to, in] the memory). ${ }^{59}$ After the meditation on the sin of disobe-

$5^{8}$ Some Brothers of the Common Life practiced writing their sins down on scraps or wax tablets (Van Engen, Devotio Moderna, 295, 298-299), a practice that Loyola apparently followed in Montserrat and which is perhaps reflected in his Exercises.

59 The importance of memory returns at the end of Loyola's Exercises in the closing prayer to gain love: "Take, Lord, and receive all my liberty, my memory, my intellect, and all my will." 
dience of angels who "hurled from heaven to hell," ${ }^{60}$ he offers the meditation on the sin of Adam and Eve, "bringing to memory the gravity and malice of the sin against one's Creator and Lord [and] to discuss with the understanding how in sinning and acting against the Infinite Goodness, he has been justly condemned forever" (51), and the meditation on one's own sins, "to bring to memory all the sins of life, looking from year to year, or from period to period" (52). Just like Zerbolt, Loyola distinguishes between the particular, daily examination of conscience, and the general one. In the former, "one ought to propose to guard himself with diligence against that particular sin or defect that he wants to correct and amend" (25), and the latter's goal is to "purify oneself and to make one's confession better, [...] ask[ing] account of our soul from the hour that we rose up to the present examen, hour by hour, or period by period," for "there is greater profit and merit [of doing it], because of the greater actual sorrow for all the sins and wickedness of his whole life" $(34,43,44)$.

\section{Role of Fear and Compunction to Produce Contrition}

Zerbolt's and Loyola's meditations on sin and God's last judgment reveal their shared psychological notion that an instigation of fear or even terror- "smitten with fear and perturbed with dread [timore percuti \& terrore perturbari]" - is salutary for uprooting inordinate affections and $\sin .{ }^{61}$ For Zerbolt, who employs the term "fear" (timor) and its synonyms in his text at least 100 times, the very first step of purification "consisteth in fear-in this step our heart is by fear withdrawn from hurtful affections and attachments" (16). Filling the heart with fear in front of "a just Judge [who] shall come with severity and dread to punish thee" is necessary to produce what Zerbolt terms "compunction" (compunctio) to contrition. ${ }^{62} \mathrm{He}$ explains in detail the relationship between the two within the context of examen of conscience as follows:

6o Zerbolt considers the sin of angels in the same order in the chapter on the remembrance of sins: "Wherefore judge thyself strictly and do this often if not continually, first of all setting this before thee and meditating thereon, namely, how greatly each sin of thine is displeasing to God, how greatly He doth abhor and detest it. In order that thou mayest be able the better to perceive this, ponder diligently, and until thou dost inwardly apprehend it earnestly consider that pride was so displeasing to God that He did not spare His creature whom once He made the noblest of all, but cast him (namely Lucifer) forth from Heaven; think, then, will He spare thee because forsooth thou art better or nobler?"

61 See Gerrits, "Inter timorem et spem," 41, 51.

62 The Merriam-Webster Dictionary defines "compunction" as "anxiety arising from aware- 
Compunction is born of fear in manifold ways. First of all when one doth bring his past sins to remembrance, and doth anxiously call to mind how greatly he hath offended God and how grievous a punishment he hath earned, and by reason of these thoughts doth weep most bitterly, in fear and trembling [tremens ac timens]. Secondly, compunction cometh when he doth diligently consider his own defects, the passions of his soul and the noxious desires that are still in him [...]; and when he doth remember, with cries and lamentation, how little is the progress he hath made in casting out these evils. Thirdly, when a man doth remember the sins that he hath committed since his conversion [...], and when with mourning and fear [temendo] he doth deplore the same. Of these three things we have spoken above in the chapter concerning the three methods of sifting and examination. Fourthly, when one doth consider that the judgements of God are inscrutable and a man knoweth not whether he be worthy of hatred or love, and that albeit he knoweth himself penitent, yet he cannot tell whether he is smitten with fear [timore percussus] only or whether he hath compunction and contrition through the grace that is infused into him; and when he is altogether smitten with dread [horrore concutitur] through his ignorance and uncertainty what shall happen to him in time to come, whether he shall be damned or saved. Fifthly, when he doth diligently ponder the shortness of his life, and understandeth that he hath made so little progress hitherto, whence he is set afire by fear [ timore succinditur], and inwardly bedewed with compunction. Sixthly, when he doth remember the strict examination and judgement to come, when the Judge shall draw near to render to every man according to his works; then, since the man knoweth his own sins, he is adread [expavescit] at this thought. Seventhly, when one doth weigh the greatness and multitude of the pains of hell, and knoweth or thinketh himself worthy of them; then doth he begin to grieve and fear [timere] mightily.

p. 17

In his meditation on hell, Loyola (to whom the goal of the entire first week of the Exercises is to produce "contrition, sorrow and tears for [...] sins") invites the exercitant to "ask for an interior sense of the pain that the damned suffer, in order that, if, through my faults, I should forget the love of the Eternal Lord, at least the fear [temor] of the pains may help me not to come into sin" (65). And in

ness of guilt." It derives from Latin "compunctio," which means "puncture" and hence the sting of conscience or remorse. 
his rules on the sentiments with the church militant (370), Ignatius reflects on the relationship between fear and abandoning sin as follows: "Although serving God our Lord much out of pure love is to be esteemed above all, we ought to praise much the fear [temor] of His Divine Majesty, because not only filial fear is a thing pious and most holy, but even servile fear-when the man reaches nothing else better or more useful—helps much to get out of mortal sin."

\section{Application of Senses and Composition of Place as a Meditative Technique}

In order to help produce compunction to interior contrition for sins, both Zerbolt and Loyola employ a combination of a technique of imagining a place to be meditated and of a method of application of senses for a thorough meditative engagement, ${ }^{63}$ for God "created thee [...] and endowed with thy five senses" (Zerbolt, 25), so that "through thine outward sense thou mightest draw to the particulars and presence before thee of things material and by thine inward sense call up to thy mind [attraheres] the images and similitude of such things, even when they are not present, through the help of reason" (2).64 Probably the best example of how Zerbolt understood these methods is his description of the meditation on hell, in which "a man, by remembering the pains of hell, doth get dread [timorem] and compunction":

Turn thine eyes [verte oculum $]^{65}$ toward the region of the damned and the prison house of the wretched, diligently considering [scrutans] what things are done therein, the condition of them that sojourn there, and what manner of place it is. But forasmuch as our mind, for its blindness'

63 Cf. Van Engen, Devotio Moderna, 300-301.

64 "Per sensum exteriorem rerum materialium particularia \& presentia, per interiorem vero \& horum etiam absentium imagines \& simulachra attraheres pro adiutorio rationis."

65 Zerbolt also uses the expressions "verte mentalem oculum" (20), "mentis tuae oculis repraesentare" (32), "propone oculis tuis imaginem" (19), and "mentalibus oculis recogitare" (31), which correspond more directly to Loyola's description of "compositio loci." This technique had been suggested in Gerard Groote's De quattuor generibus meditabilium [On four kinds of matter for meditation] (c. 1378). See Jan van Herwaarden, Between Saint James and Erasmus: Studies in Late-Medieval Religious Life; Devotion and Pilgrimage in the Netherlands (Leiden, 2003), 5-7; Rudolf Th.M. van Dijk, "Toward Imageless Contemplation: Gerard Zerbolt of Zutphen as Guide for Lectio Divina," in Spirituality Renewed: Studies on Significant Representatives of the Modern Devotion, ed. Hein Blommestijn, Charles Caspers, and Rijcklof Hofman (Leuven, 2003), 3-25. 
sake, is better led by things visible and sensible to the understanding of the invisible, thou canst put before thee the images [assumere similitudines] set forth by saints in the Holy Scriptures concerning this matter, so that thou mayest the better apprehend [sentias] the pains that are there. Consider [aspice] then the chaos of hell, a place most dread beneath the earth and very deep; all dark it is, a well that is without bottom and all afire. It is a furnace glowing and flaming in dreadful wise, and this vast region is dark and murky but all aglow and heated, and it is filled with a multitude of people unnumbered, all crying aloud and uttering sounds of woe, calling out for pain and burning, and gnawing one another for every malice as though they were foul dogs held together in leash. Then consider [cogita $]^{66}$ the grievous nature of the punishment. There is an overwhelming heat, to which our heat here is in no wise comparable. There is cold that none may bear, to which no cold that is known in this earth can be made to bear likeness even by comparing them. Think [cogita] then of the exquisite nature and the torment of each pang, the numberless pains there are. It is a fire that never shall be quenched, an ardent heat that yet doth give no light. There is cold that cannot be borne with fetor must foul, darkness that may be felt and worms that die not; pains ravage every sense and every limb. Thine eye shall see [videbit] the spawn of hell that by the terror of their aspect do wondrously afflict them that look thereon; thine ears shall hear [audit] naught but lamentation and moaning and savage cries.

p. 21

Loyola instructs the exercitant that "it is helpful to pass the five senses of the imagination through $[. .$.$] meditation: to see the persons with the sight of the$ imagination [...]; to hear with the hearing what they are [...]; to smell and to taste [...]; to touch with the touch" (121-125). His method of application of senses is also best seen in the meditation on hell (65-70), through which "at least the fear [temor] of the pains may help me not to come into sin": "The first point will be to see with the sight of the imagination [ver con la vista de la imaginación] the great fires, and the souls as in bodies of fire. The second, to hear with the ears [oir con las orejas] wailings, howlings, cries, blasphemies against Christ our Lord and against all His Saints. The third, to smell with the smell

66 The verb cogitare (to think, to consider), one of most frequent words used in the Spiritual Ascents, indicates the mental process involved in meditating. Zerbolt also uses an expression "in corde cogitando" (1). On the use of this verb in Loyola's Exercises, see Melloni, Exercises of St Ignatius, 27-28. 
[oler con el olfato humo] smoke, sulphur, dregs, and putrid things. The fourth, to taste with the taste [ gustar con el gusto] bitter things, like tears, sadness and the worm of conscience. The fifth, to touch with the touch [tocar con el tacto]; that is to say, how the fires touch and burn the souls."

\section{Role of Compunction to Produce Hope and Love}

For both Zerbolt and Loyola, the compunction to fear is not, however, the end but a means to move on in the spiritual exercises toward full love of God. Zerbolt advises that "yet oughtest thou to direct this method of meditation, or one like to it, in such a manner that thou fall not into despair [in desperationem]" (6), "for hope doth infuse [ingerit] into the affections the savour for things eternal, and doth restore them again to the love of what is higher [superiora]" (22). In order "to have more confidence [ fiduciam $]^{67}$ to hope for, and to attain, future glory," Zerbolt instructs the reader that "thou oughtest sometimes to turn over carefully in thy mind the tokens of love [signa dilectionis] ${ }^{68}$ the Lord hath shown thee, and to ponder yet more diligently upon the benefits [beneficia] that he hath done, and by these thoughts to be stirred [accendi] as by goads [stimulis] to love him again [ad re-amandum]" (25). This transition from fear to love can be achieved mainly by meditating Jesus's passion, for from this source [...] shall flow to thee by turns hope and devotion, and those most precious unguents that are compounded of fear, love, thankfulness [gratitudo], compassion, and the like [...]. To the end that the toil [labor] may not make thee afraid [terreat], nor the bitterness [amaritudo] deter [deiiciat] thee; that hope may draw thee and devotion lead thee on; that thankfulness [gratitudo], love and compunction may constrain [cogant] thee to ascend the mount of purity; first go to Christ as thou dost spy out the way [speculando]; for he may be called, and not unfittingly, the Mountain of Myrrh, by reason of the bitterness [amaritudinem] of his most grievous [acerrimae] passion. To him must thou go first of all, collecting eagerly, and impressing [imprimendo] upon thine heart devout thoughts of his passion, to be as it were thy first gathering of myrrh [32].

Meditating Christ's passion, so central to his work, can be helpful to lead to what Zerbolt calls the third ascent against vainglory and Loyola the third (most perfect) grade (manner) of humility. According to Zerbolt, this is achieved

67 Latin fiducia is of course etymologically related to fides (faith).

68 Loyola speaks of the need to recognize "beneficios recibidos" [43], [234]. 
"when a man hath blown out the lamp of vanity and overthrown it, he doth so greatly love [diligit] lowliness [abiectionem] and contempt of the world [despectum mundi] that sometimes, even in the face of the multitude, he will do or undertake something whose fulfilment shall bring abject ignominy [ignominiam], and that for love of lowliness [ex amore abiectionis] and a desire [appetitu] to be held in light esteem [ignominiae]" (62). For Loyola, that manner of humility is reached when "I want and choose poverty [pobreza] with Christ poor rather than riches, opprobrium [oprobrios] with Christ replete with it rather than honors; and to desire to be rated as worthless and a fool [ser estimado por vano $y$ loco] for Christ, who first was held as such, rather than wise or prudent in this world" (167).

Spiritual Consolation and Discernment of Spirits

The transition from fear to hope and love "in the persons who are going on intensely cleansing [purgando] their sins and rising from good to better in the service of God our Lord" (315) is marked according to Loyola by what he calls "spiritual consolation," through which "the soul comes to be inflamed [inflamarse] with love [amor] of its Creator and Lord," that is, every "increase of hope, faith, and charity [caridad], and all interior joy that calls and attracts [atrae] to heavenly things [cosas celestiales] and to the salvation of one's soul, quieting it and giving it peace in its Creator and Lord," including shedding tears "out of sorrow [dolor] for one's sins, or for the Passion of Christ our Lord" (316).

Even if the exact term does not appear in Zerbolt's work (Loyola probably borrowed it from Cisneros or à Kempis), ${ }^{69}$ he describes the same reality of spiritual consolation with other common terms. Zerbolt speaks, for example, of "being enkindled to a fuller and more fervent affection [pleniori affectu \& ferventiori accensus]" (61); how "a man, by being mindful of the benefits that God hath done him, is inflamed in devotion and kindled to compunction [inflammatur ad devotionem \& accendatur ad compunctionem]" (25); how man "is kindled to the love of the Creator [in amorem accenditur creatoris] by the knowledge of the creature and its beauty" (26); how "being smitten of fear, weighed down of compunction, and being likewise inflamed with affection and desire for the upward way [timore percussus \& compunctione depressus, affectu quoque \& desiderio ascendendi inflammatus]" (44); and how one should read those books that "increase devotion in thee, and inflame thy affection

69 See, for example, Cisneros, Exercitatorio, 64. 
toward Christ and things heavenly [augent devotionem \& inflammant affectum ad Christum \& ad coelestia]" (44).

Zerbolt's equivalent of "spiritual consolation" is "devotion" or "delight" (delectatio), which he describes as "a sweet affection, or a leaning of the affections towards good [inclinatio affectuosa ad bonum], or an incitement [incitatio] that draweth them [trahens affectum] in pleasant wise [dulciter]" (49). Anticipating Loyola's rules for the discernment of spirits, Zerbolt notes in that chapter that the way of discerning (discretio) these "sweetest and pure affections" is different for those who begin to have "a devout inclination to seek good, or avoid evil, and a sweet leaning thereto" but are often "taken in the snare of the enemy and in the hunter's toils" and those who "after long strife and many exercises and with the cooperation of the grace of God, hath already made vice itself subject to the rule of reason, [are] clad as it were with a natural affection toward what is good, taketh sweet pleasure in it and doth rest therein [and are] ever ready to fulfil the good pleasure of God whether it be any work or suffering."

Zerbolt also explains that this devout inclination "may come through the gift of God [ dono Dei], which is often poured down from on high [quod desuper frequenter infunditur]." This gift of God seems to be echoed in Loyola's second rule for the discernment of the spirits (330): "It belongs to God [es de Dios] our Lord to give consolation to the soul without preceding cause [dar consolación a la ánima sin causa precedente], for it is the property of the Creator to enter, go out and cause movements in the soul [entrar, salir, hacer moción en ella], bringing it all into love [trayéndola toda en amor] of His Divine Majesty."

Moreover, Zerbolt also describes a spiritual condition Loyola calls "spiritual desolation": "So it doth come about that his soul being affected by weariness and finding no consolation, he doth straightway desert his post or falleth into somnolence or dissolute manners [Itaque cum anima taedio affecta nullam consolationem invenit, statim locum deferit, aut in somnolentiam incidit vel dissolutionem]" (61). In his chapter on fighting against the vice of avarice (61), he writes about the state of "sadness that cometh of despair" and offers a remedy for it"the remembrance of the kindness and mercy of God and the perception of His benefits."

The transition from fear to hope and love is ultimately possible because of Zerbolt's and Loyola's shared ontological notion of God as the Sovereign Good (summa bondad; summum bonum), ${ }^{70}$ the Infinite Goodness (bondad infinita),

70 See Gerrits, "Inter timorem et spem", 48, where he argues that Zerbolt borrowed this expression from Augustin perhaps via the Franciscan David of Augsburg. It is interesting to 
Most Supreme Blessedness (beatissima beatitudo), the Marvelous God (Deus admirabilis), the Father kind and bountiful (Pater dulcis et benignus), and most of all Creator and Lord (Creator, Criador; Dominus, Señor), "the beginning of all things [omnium principium]" and "the first cause of all things [prima causa omnium], who created thee after his image and similitude placed thee of old on so lofty a height of worthiness [sublimi dignitate] and set thee upon so high a mountain of natural gifts and graces that scarce couldst thou have ascended higher unless thou hadst gone forward to the essential vision of God" (Zerbolt, 2) and who "communicate[s] himself [se communique] to his devout soul, inflaming it [abrasándola $]^{71}$ with his love and praise, and disposing it [disponiéndola] for the way in which it will be better able to serve him in future" (Loyola, 15).

The idea that human affections can be exercised to produce contrition and love, as if it were a work of an urban craftsman, ${ }^{72}$ reveals Zerbolt's and Loyola's shared optimistic anthropological and theological view on human will—one of the "three powers of the soul."73 At the outset of his work, Zerbolt reminds the reader that "by thine own will thou art fallen into a deep valley" (1), and at its end he envisions - in the tradition of Jean Gerson $\left(1363^{-1429}\right)^{74}$ - a contemplative man high on a mountain who is capable of "searching out [perscrutantur] the sentence of the Heavenly Will" (70). In Zerbolt's words, will is a gift of God "to the end that thou mightest love God above all, and other things for His sake; and that in loving them thou mightest ascribe them duly to Him" (2).

note that David's De exterioris et interioris hominis compositione was occasionally printed together with Zerbolt's De ascentionibus, as, for example, in the 1498 Cologne edition at http://www.worldcat.org/oclc/765479958 (accessed December 7, 2020).

71 In the context of Zerbolt's comparison, "abrasar" (to sear) makes more sense than "abrazar" (to hug). See http://web.frl.es/DA.html (accessed December 7, 2020); cf. Iparraguirre and Dalmases, Obras de san Ignacio, 224-225n12.

72 Van Engen, Brothers and Sisters, 79.

73 See Zerbolt, 3: "Original justice being lost by this very fall, and by the just judgement of God, our powers and affections, having lapsed from their former state, are alike minished and disordered; yet are they not wholly destroyed, but being impelled in a direction contrary to their former inclination, they do oppose and strive the one against the other in their motions and impulses."

74 See Jean Gerson, De monte contemplationis [On the mount of contemplation]. 
Free will is a key term in Loyola's opening Principle and Foundation: "For this, it is necessary to make ourselves indifferent to all created things in all that is allowed to the choice of our free will and is not prohibited to it," and in the contemplation to gain love that closes his text, the exercitant should be capable of transforming their own will into God's, "All is Thine, dispose of it according to all Thy will" - the very purpose of the entire course of the Exercises: "To rid itself of all the disordered tendencies, and, after it is rid, to seek and find the Divine Will."

Loyola's final prayer asks, however, for God's grace, which needs to accompany human efforts to exercise free will. Indeed, the exercitant should ask for God's grace at the beginning of each exercise in so-called preparatory prayer that "all my intentions, actions, and operations may be directed purely to the service and praise of His Divine Majesty": grace to remember, to know, and to hate sins; grace to amend; grace to imitate Christ; grace to make good election, and so on, for, after all, "no one can save himself without [...] having faith and grace."

Not surprisingly, Loyola's theological balance between God's grace and human will echoes Zerbolt's approach-"thine own diligence [industria] is nothing save the grace of the Lord attend [comitetur] thee in all things" (1). He explains well the cooperation of God's grace (divina cooperantia gratia [49] or divina adiuvante gratia [57]) with man engaged in spiritual exercises in chapter 26: "For all this state of perfection may be attained by no man except it be by the special grace of God, which grace is not given to sleepers, to the negligent nor to them that will not work together [non cooperantibus] with him [...]; men may climb up to this height step by step, and come near to it, by daily exercises." And in his advice against the vice of pride (63), Zerbolt suggests the following prayer: "Not I, but the grace of God that is with me; by the grace of God I am what I am: it is God that worketh both to will and to do according to His good pleasure [operatur velle \& perficere pro bona voluntate]."

\section{Role of External Guidance in Spiritual Exercises}

Beyond this possibility of direct relationship between God and the exercitant, both Zerbolt and Loyola see the need for objectivity in one's spiritual exercises. ${ }^{75}$ Zerbolt dedicates a chapter to this topic, in which he explains why "it is

75 With the same purpose, the Devotio Moderna developed the practice of personal and communal admonition (correction). See Van Engen, Brothers and Sisters, 282-288. 
expedient or necessary [sit expediens vel necessarium] for a man who is going forward in spiritual exercises to have for guide a man that is spiritual":

Go not up without a guide [ductore] nor go forward save with one who knoweth the way [viam] and is not ignorant of the wiles of the enemy [astutias hostium non ignorat]. Often God doth use to instruct a man by means of other men, and so to admonish him that he take the right ascent and the true paths. Woe to him who trusteth in himself and goeth forward alone, without a guide [ductore], for easily he falleth into the snares of the hunter, and having fallen therein he hath none to lift him up. [...] Choose thee a guide [ductorem], a man spiritually minded, and be earnest to perform all thine exercises and fulfil them led by his learning, admonishment, and examination.

p. $5^{1}$

And in the subsequent chapter, Zerbolt points out that having a spiritual guide is a condition to fight against inordinate affections: "If then, thou hast gotten thine armour and hast found a guide to go before thee with counsel and direction [si ductorem qui te praesedat consulendo \& dirigendo invenisti], it is time to get to the fight, and so thou must strive against all inordinate affections" (52). Moreover, in the preparatory section of the exercises, he advises the exercitant that if he does not know what exercises serve better for their spiritual progress, "they should ask somebody else [alios interroga] or even have them prepare the exercise [per alios dispone ascensum] for them. After all, the order of the exercises needs to be approved by some spiritually minded man [spiritualis viri discussione approbata]" (9). ${ }^{76}$

Loyola, in the thirteenth rule for the first week (326), writes: "When the enemy of human nature [el enemigo de natura humana] brings his wiles and persuasions [astucias y suasiones] to the just soul, he wants and desires that they be received and kept in secret; but when one reveals them to his good confessor or to another spiritual person that knows his deceits and evil ends [su buen confessor o a otra persona spiritual que conosca sus engaños y malicias], it is very grievous to him, because he gathers, from his manifest deceits being discovered, that he will not be able to succeed with his wickedness begun." And

$7^{6}$ Zerbolt uses the verb "disponere" (to arrange, to determine). Loyola's equivalent is the verb "disponer," which he employs in the very first annotation, speaking about "preparing and disposing the soul for getting rid of all inordinate affections" (disponer el ánima para quitar de sí todas las afecciones desordenadas). He also speaks about a "disposition" of a person, by which he means "age, education or ability" (annotation 18) or of life (annotation 1). 
in the seventh annotation, Loyola points out how the spiritual guide should be experienced in recognizing the movements of various spirits: "If he who is giving the Exercises sees that he who is receiving them is in desolation and tempted, let him not be hard or dissatisfied with him, but gentle and indulgent, giving him courage and strength for the future, and laying bare to him the wiles of the enemy of human nature [descubriéndole las astucias del enemigo de natura humana], and getting him to prepare and dispose himself for the consolation coming." It is interesting to note here that both Zerbolt and Loyola do not necessarily identify the spiritual guide with a priest (confessor). The former defended the Devout Brothers' practice of also seeking spiritual counsel from a lay guide - an expert in spiritual life — to whom even sins could be confessed non-sacramentally. ${ }^{77}$ Confessor and spiritual guide, however, could also be the same person. Zerbolt encourages the reader to "choose such a confessor as doth know how to remit or retain sins with discretion and prudence, for to such an one thou canst commit thy soul with confidence [ fiducialiter]; to him thou canst safely reveal [secure exponere] thy state, thy life, and all thine exercises, as to one from whom thou shalt receive counsel in each several matter" (13). In his earlier De reformatione, Zerbolt is even more explicit in his call for the need of advice from others: "If you do not believe yourself or if you are unable to discern [indiscretus], discernment should be replaced by obedience [locum discretionis suppleat obedientia] to some man who is more important [clarus] and more knowledgeable [illuminatus] than you" (16).

Even if Zerbolt does not address directly the spiritual guide in the grammatical sense - he, the author, is the guide — his text does contain advice on approaches to exercitants. Zerbolt points out that "concerning the step upon which a man ought to exercise himself more fully, discretion must be used [discretione opus est] so as to discriminate [ut discernatur] herein according to the progress, state, and condition of each several person" (65). This accommodation is reflected in Loyola's text where he advises that the exercises should be adapted to help the person who is exercising "according to age, disposition, and physical condition" (72).

Zerbolt's passage contains two crucial terms associated traditionally with Ignatian spirituality: "discretion" and "discernment" (discreción, discernimiento; Lat. discretio). He employs them also in his advice on how to discern the nature of what he calls "devout inclinations." In his chapter dedicated to the origin of affection, he writes: 
For to have true joy in the Lord is this, to rejoice in charity, chastity and humility, but other devout inclinations may sometimes be deceitful [deceptoriae]. And verily to the end that thou mayest have sound discretion [habeatur aliqua discretio] in this matter, so far as sufficeth the present purpose, thou must know that devotion doth mean a sweet affection, or a leaning of the affections towards good, or an incitement which draweth them in pleasant wise. But such delight or affection may be twofold, or may arise from two causes; for sometimes such an affection is one that suddenly cometh and quickly goeth, although it may by times shake the mind vehemently: and this doth seem to arise from a desire for some object of appetite or love.

p. 49

The aim of this essay was to show the multifaceted convergence between Gerard Zerbolt of Zutphen's De spiritualibus ascentionibus and Ignatius of Loyola's Exercicios spirituales, which-just like Erasmus of Rotterdam's Enchiridion militis christiani but unlike à Kempis's Imitatio Christi-belong to the same genre of practical spiritual guide that was characteristic of the Devotio Moderna tradition between the late medieval and early modern periods. ${ }^{78}$ Employing art historian Michael Baxandall's (1933-2008) concept of "influence" from his Patterns of Intentions (New Haven, CT, 1985), ${ }^{79}$ this essay invites the reader not just to acknowledge that what some scholars consider Loyola's unique contribution to modern religiosity was sourced in Zerbolt's work but also to investigate how the success of Loyola's Exercises allows a repositioning of the Devotio Moderna and the many spiritual writers who are indebted to it. To use Baxandall's metaphor, we should see not only how the billiard ball X (Zerbolt) hit the billiard ball Y (Loyola) but also how balls X and $Y$ hit many other balls on the billiard table of spiritual theology, including not only Groote, à Kempis, Standonck, Cisneros, Mombaer, Erasmus, and Calvin, who were mentioned in the introduction to this essay, but also-among many others-

\footnotetext{
78 See Gerrit Gerrits, "A Comparison of Erasmus' Handbook of the Christian Knight with Thomas a Kempis' Imitation of Christ and Gerard Zerbolt's The Spiritual Ascents"; https:// caans-acaen.ca/Journal/issues_online/Issue_XXVI_i_2005/GERRITS.pdf (accessed December 7, 2020). Traditionally, scholars saw similarities between Erasmus and à Kempis, but there is actually more similarity between Erasmus and Zerbolt.

I am indebted for this reference to Simon Ditchfield of York University.
} 
Hendrik Herp (c. 1400-1477), ${ }^{80}$ Martin Luther (1483-1546), ${ }^{81}$ Jacques Lefèvre d'Etaples (c. 1450-1536), ${ }^{82}$ Francisco de Osuna (1497-1541), ${ }^{83}$ Gasparo Contarini (1483-1542), Juan de Ávila (1499-1569), ${ }^{84}$ Teresa of Ávila $\left(1515^{-1582)},{ }^{85}\right.$ Pierre de Bérulle (1575-1629), ${ }^{86}$ and François de Sales $(1567-1622),{ }^{87}$ with the cue-ball being not $\mathrm{X}$ (Zerbolt) but $\mathrm{Y}$ (Loyola).

8o See, for example, Rik van Nieuwenhove, "Catholic Piety from Ruusbroec and the Devotio Moderna to the Legacy of Pierre de Bérulle," in The Oxford Handbook of Catholic Theology, ed. Lewis Ayres and Medi Ann Volpe (Oxford, 2019), 577-584, there $582-583$.

81 See Gerrits, “Inter timorem et spem", 6-9, where he challenges Hyma's thesis of Zerbolt being a forerunner of the Protestant Reformation.

82 See, for example, Byung-Ho Moon, Christ the Mediator of the Law: Calvin's Christological Understanding of the Law as the Rule of Living and Life-Giving (Milton Keynes, 2006), 46.

83 See, for example, David William Kling, A History of Christian Conversion (Oxford, 2020), 241.

84 See, for example, David Tavárez, "Nahua Intellectuals, Franciscan Scholars, and the 'Devotio Moderna' in Colonial Mexico," The Americas 70, no. 2 (2013), 203-235, there 203, 231; Rady Roldán-Figueroa, "Ignatius of Loyola and Juan de Ávila on the Ascetic Life of the Laity," in A Companion to Ignatius of Loyola: Life, Writings, Spirituality, Influence, ed. Robert Aleksander Maryks (Leiden, 2014), 159-177, there 160.

85 See, for example, Barbara Mujica, "Beyond Image: The Apophatic-Kataphatic Dialectic in Teresa de Ávila," Hispania 84, no. 4 (2001), 741-748, there $742 \mathrm{ff}$.

86 See, for example, Keith Beaumont, "Pierre de Bérulle (1575-1629) and the Renewal of Catholic Spiritual Life in France," International Journal for the Study of the Christian Church 17, no. 2 (2017), 73-92.

87 See, for example, Van Nieuwenhove, “Catholic Piety," $5^{8} 3$. 